\title{
Flood and Female Headed Households in Illah Rural Community of Delta State, Nigeria
}

\author{
Ezemonye, Mary. N \\ 1Department of Geography and Regional Planning, University of Benin, Benin City, Nigeria \\ Email: ezemonyemary@yahoo.com
}

\author{
Doi:10.5901/ajis.2015.v4n2p109
}

\section{Abstract}

Flash floods are common features in Nigeria during the rainy season (May-October), but the flood events of August-October 2012 in Nigeria which can be described as the worst in 40 years gave rise to situations where rivers overflowed their banks and submerged hundreds of kilometers of urban and rural lands. Flood disasters are major threats to human-beings and reverse major developmental processes in any locality, hampering socio/economic activities. Most of the rural areas affected by this flood have high poverty levels and many Female headed households. The poverty level affects the resilience and process of recovery from the flood disaster especially for the Female Headed Households as they are more vulnerable to flood impacts. Flood disaster mitigation in Female Headed Households needs to address socio-economic issues and coping strategies. This paper seeks to communicate the impact of the floods on the socio-economic status of livelihood and the coping strategies of female headed households in Illah community and environs of Delta State, Nigeria. Utilizing structured questionnaires and focus group discussions/interviews the study identified that the major livelihood of sampled female Headed households were crop production. $100 \%$ of the female headed households had their crops damaged and mainly the staple crops thus increasing food insecurity for the households. Their incomes were affected significantly as income source is imbedded in livelihood. This reduction in income also increased their vulnerability. The ANOVA test shows that there is a significant difference among households in terms of their flood coping strategies. Utilizing the factor analysis it was identified that the coping strategies employed by female headed households is majorly a function of three factors namely: poverty, area of residence and location of economic activity and lack of alternative livelihood. The current coping strategies being employed by female headed households are ineffective. There is a dire need for the female headed households to be given priority in times of aids provision during and after any natural disaster. Efforts are to be made by the communities at formulating sustainable mitigation measures in order to enhance community resilience in view of frequency/magnitude of floods experienced. Adequate funding towards risk mapping, monitoring and implementation of preparedness/mitigation measures should be implemented.

Keywords: Flood disaster, Female headed households, Food security, Vulnerability, Resilience, Coping strategies

\section{Introduction}

Floods are the most reoccurring, widespread, disastrous and frequent natural hazards of the world (Odufuwa et al 2012, Uddin et al 2013). A flood is an overflow of an expanse of water that submerges the land. They can be viewed as lethal hydro- meteorological disasters with far reaching effects on life and property. According to Smith and Ward (1998), there is more evidence that the flood problem is getting worse in terms of the damage caused by flooding floods are the most taxing of water related natural disasters to humans, material assets as well as to cultural and ecological resources as it affects people and their livelihoods. Borrows and De Bruin (2006) and Kolawole 2013 are of the opinion that among natural catastrophes, flooding has claimed more lives than any other single natural hazard, affecting more people on an annual basis than any other form of natural disaster.

The African continent has not been spared by floods. According to UNEP (2006), the continent is more vulnerable than any other continent to climate change. Parker (2000) observed that in many African countries, floods create great natural threats to life, health and population as the combination of this natural hazard and human vulnerability result in intense disasters. Natural disasters can have major impacts on the social and economic welfare of a population, and often pose serious obstacles in the achievement of sustainable social and economic development. Nigeria in recent times has experienced several emergency situations that resulted from environmental disasters with some being natural and a number of others being related to human activities. According to Abayomi and Oyekale 2013, Flooding as a natural disaster affects at least $20 \%$ of the Nigeria's population and as noted by EMDAT disaster database in Nigeria, flooding affected more than three million people in selected urban areas between 1983 and 2009. This led to loss of many lives and destruction to the environment which is the source of people's livelihood. The recent heavy rains and opening of the dam by Cameron in 2012 led to an overflow of the Niger River resulting in flash floods in Nigeria occasioned by the 
combined effects of none preparedness and human vulnerability. This affected the poorest and the riverine areas the most. Vulnerability along the coast stems from moderately high physical exposure Busby, Smith, and White (2011).

According to UNISDR (2009), "two elements in combination increase or decrease disaster risk: a potentially damaging eventor phenomenon (hazard) and the degree of susceptibility of the elements exposed (vulnerability). Mirza, et al (2003) are also of the view that flood disaster has different impact on individuals, households and communities. This is basically because of their differences in exposure and coping capability. Usually flood-affected households reside in an environment of complex and multi-faceted vulnerability, and this has a negative impact on their ability to withstand and recover from major flood events. It is noteworthy that impacts from disasters are not uniformly distributed within a population and they tend to disproportionately affect the poorest and most marginalized groups in any environment.

Disasters affect men and women differently because of the different roles they occupy and their different cultural responsibilities. Rashid (2000), Ariyabandu and Wickramasighe (2005) and (Enarson, 1998) suggest that women are often more vulnerable to disasters than men (also owing to conventional gender responsibilities and relations). Flood thus impacts directly on women because of their roles as providers of food, water and fuel. Women often experience higher rates of mortality, morbidity and post-disaster diminishment in their livelihoods. Several underlying factors exacerbate women's vulnerability to the impacts of disasters, such as lack of means to recoup lost assets, limited livelihood options, restricted access to education and basic services, and in many cases, also socio-cultural norms.

Literature also suggests that female-headed households have limited access to resources (Mbugua, 1997; Oppong, 1997; World Bank, 1991). International comparisons, and analyses of household surveys have further pointed out that female-headed households are in general among the poorest and most vulnerable (Cain, Khanam and Nahar, 1979; Caldwell,Reddy and Caldwell, 1984; Islam, 1993; Amin, 1996; Buvinic and Gupta, 1997; Rahman, 1998; Quisumbing, Haddad and Pena, 2001). The poverty level affects the resilience and process of recovery from disasters. Vulnerability is a key concept in predicting and understanding the existence of differentiated impacts on the various groups in a society (Blaikie et al, 1994). Vulnerability as pointed out by Dixit (2003) is the condition of a person or group in terms of their capacity to anticipate, cope with, resist and recover from the impact of a natural hazard. The different needs, opportunities and risks facing women and men, are important elements when defining vulnerability and has implications for emergency response, recovery and long-term development of a given region or country. Nigeria is one of such societies where these differences increase the differences in their capacities, needs and vulnerabilities. By taking into account the different impact of disasters on female headed households which are increasing in the rural communities, policies and interventions for sustainable recovery and reconstruction as well as for risk reduction, preparedness and mitigation programs can become more effective and targeted. Disaster mitigation, preparedness and prevention thus need to address socio-economic issues in female headed households in this climate change times. The aim of this study therefore is to evaluate the impact of the 2012 flood on the livelihood and the coping strategies of female headed households in Illah community and environs of Delta State as well as examine implications for policy and intervention measures.

\subsection{Study Area}

Illah community is found in Oshimili North of Delta State, Nigeria. It is an Igbo speaking community that lies on the west bank of the River Niger. It lies within latitudes $6^{\circ} 25^{\prime} 26^{\prime \prime} \mathrm{N}$ and longitude $6^{\circ} 38^{\prime} 56^{\prime \prime} \mathrm{E}$ (fig 1) and lies at 201 meters above sea level.

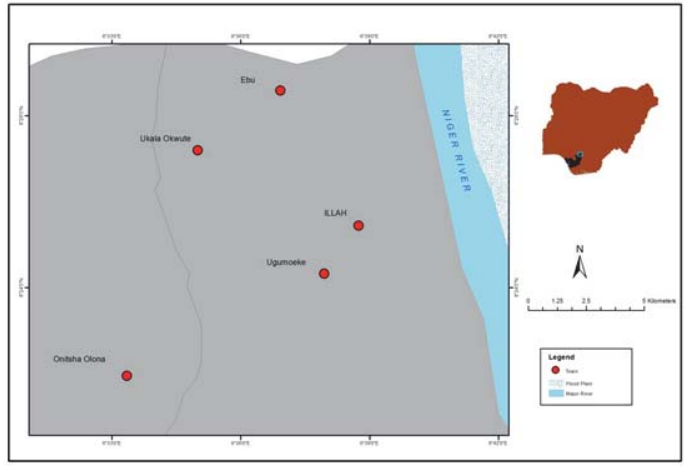

Figure 1: Illah and environs, Delta state, Nigeria. 
Illah is a heterogeneous society made up of nine villages namely and each headed by the eldest male known as the "diokpa". Politically it is governed by council of elders consisting of the head of the nine villages and a number of obis headed by the "Ogbelani". The community is blessed with natural resources ranging from fertile land to oil potential discovered in 1980 but yet unexplored. About $98 \%$ of the people are farmers thus the community is predominantly a farming community. It has a major market situated at the bank of River Niger (Otu Umutei or Otu Eke) and it is operated on the bases of the native market day pattern (ie once every four days). Other markets exist at the upland area and these are Otu Onyia, Otu Ukpologu and Afia Eke. These markets attract traders from outside the rural community because of the various foodstuff sourced from the area and their low prices. They are known for the production of staple crops such as cassava, yam, cocoyam and maize. Fishing is also predominant in the community. Thus the livelihoods of Illah residents depend to a very large extent on agriculture and fishing.

\section{Materials and Methods}

This study was carried out in two phases: during the flood and after the flood and spanned through the period September 2012 to December 2013. A total of 239 female headed households affected by 2012 flood were identified at the beginning of the study period (September 2012, when they were sheltered in a school in the community) or sharing shelter with family members and interviewed. Simple Random sampling procedure was used to identify households selected to participate in the study. This was however governed majorly by the willingness of the household to participate. The head of each female headed household was the major respondent.

Structured questionnaires, focus group discussions and in-depth individual discussions were utilizes in obtaining information related to impacts of the flood, income generation sources ( livelihood sources), coping strategies and adjustment levels to the 2012 flood.

This study is based largely on descriptive statistic such as percentages, pie chart, Analysis of variance and the Factor analysis tests. For this study, Data Entry Screens were developed in SPSS for Data Entry Version 3.This applied to the quantitative data collected. The qualitative data was coded and entered into MS Excel before being transported to SPSS.SPSS Windows Version 11.5 was used for the analysis.

\section{Results/Discussion}

The findings of this study shows that female headed households of various categories (able 1) exist in the community as 293 female headed with the Females that have separated from their husbands being the highest $(24.6 \%)$ of the total number of female headed households affected by the 2012 floods.

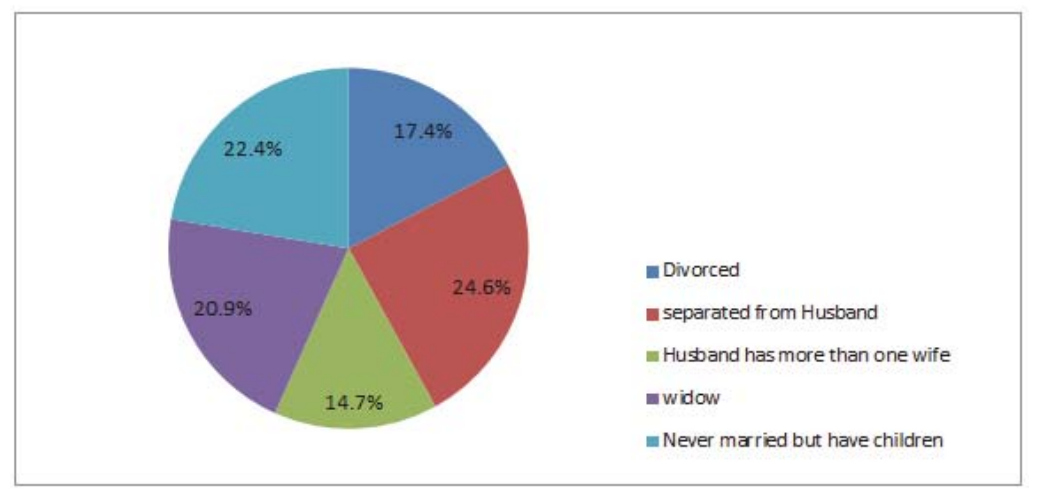

Figure 1: Categories of Female Headed Households affected by the flood in Illah

The livelihood patterns associated with female headed households in the study area were identified to range from $f$ and this is shown as Fig 2. Figure 2 shows that the major occupation among this group is farming as $66.6 \%$ of the female headed households engage in farming ( crop production), $20 \%$ in trading, $7.8 \%$ are public servants and only $5.6 \%$ engage in fishing. 


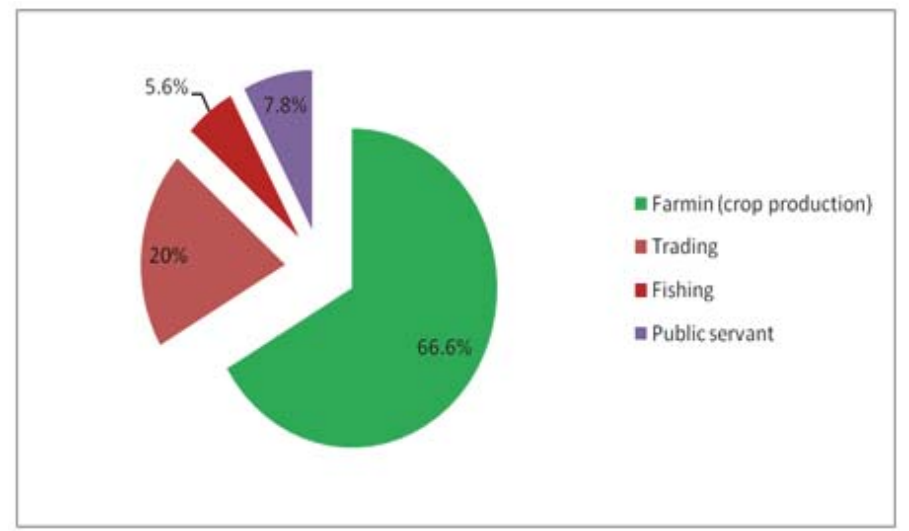

Figure 2: Livelihood Pattern among female headed households in Illah

The high percentage (66\%) that is involved in farming highlights the fact that the community is an agrarian community. 195 female headed households involved in farming indicated that during the 2012 floods, they all lost their crops. The crops most affected were the staple crops (table 3). As depicted in table 3, the staple crops lost were yams/yam seedlings, cassava, maize and cocoyam. All the female headed households indicated that the major staple crops that were most affected was yam and cassava. This is because the staple crops had not been harvested and most of the yam barns were pushed down by the force of the flood waters while the cassava farms were permanently water logged for more than four months thereby aiding the rooting of the root crops. The estimated value of the staple crops lost per household ranges from 100,000 to 150,000 Naira.

Table 3: Crops lost by the female headed households (farmers) during 2012 floods

\begin{tabular}{|c|c|c|}
\hline Crop types lost during 2012 floods & Number of households affected & Average amount lost per household( in Naira) \\
\hline Yams/Yam seedlings & 195 & $100,000.00$ \\
\hline Maize & 172 & $50,000.00$ \\
\hline Cassava & 195 & $50,000.00$ \\
\hline Melon & 89 & $15,000.00$ \\
\hline Cocoyam & 83 & $22,000.00$ \\
\hline
\end{tabular}

Source: field work 2013

To appreciate the impact of the floods on the female headed households' livelihood and income, the households were asked to indicate their income before, during and after the floods. The average income of the female headed households and their various occupations are thus shown as Fig 4.

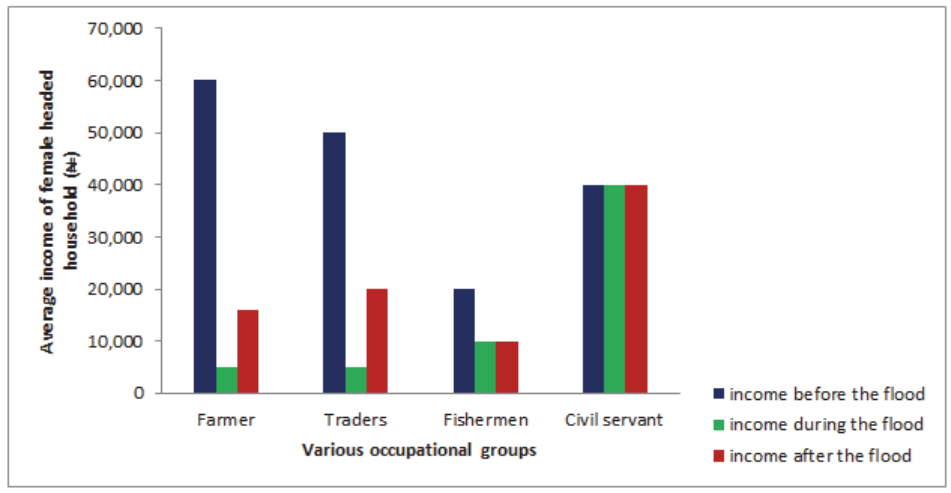

Figure 4: Overview of the average income of female headed households (pre, during and post disaster) 
From figure 4, it can be seen that in the case of the farmers the average income from the crop sales were higher before the floods (60,000 naira) than during the floods (5,000 naira). The drop in sales was majorly due to loss of crops especially those that were not yet harvested and affected by the flood waters plus their relocation to shelters provided by the State government. As indicated by the households, what they considered as income during the flood period were mainly monetary gifts from friends and families. Their incomes after the floods have also remained lower than before the flood, (on average (16,000 naira) per household). The same pattern of reduction in income during the floods and minimal increase after the floods is observable for the traders and fishermen. The only occupational group that did not have their income directly affected by the floods is the public servants who were still able to keep their jobs and earn the same salary while living in the shelter.

The aftermath of the floods on female headed households shows that the female headed household farmers that depended on agriculture as their main source of livelihood had only $90(46.2 \%)$ households continuing with farming as their major source of livelihood; $40(66.7)$ as traders, 8(50\%) as fishers and 100\% as public servant. 133(45\%) have remained either unemployed or relocated from the community. This is explainable by the inability of some of households to generate funds to return to their former occupations, fear of a repeat event, high interest loans charged by local money lenders and unavailability of employment.

The coping strategies adopted in the study area ranges from forced temporary migration to changing means of livelihood to another (Fig 5). The coping strategy most practiced is forced temporary migration, while the least is changing means of livelihood,

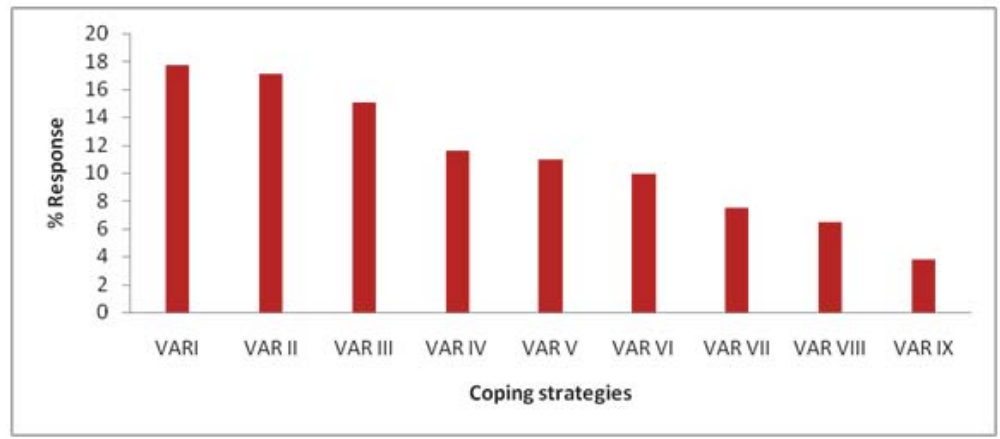

Figure 5: Flood coping strategies adopted by the female headed households in Illah.

VAR I: Forced temporary migration

VAR II: Cultivation on small portion on higher ground

VAR III: Forced asset sales

VAR IV: Increased indebtedness through borrowing

VAR V: Relocation from flood plain to higher ground

VAR VI: Changing crop planted to less capital intensive crops

VAR VII: Switching to being farm hand

VAR VIII: Remaining unemployed

VAR IX: Changing means of livelihood to another business

To ascertain if there is any significant difference among households in terms of their coping strategies, it was hypothesized that there is no significant difference among the female headed house in terms of their coping strategies. To test the hypothesis, an ANOVA test was conducted and the result is shown as (table 4).

Table 4. Analysis of variance of female headed household coping strategies.

\begin{tabular}{|c|c|c|c|c|c|c|}
\hline Source of Variation & SS & Df & MS & F & P-value & F crit \\
\hline Between Groups & 317.64 & 8 & 39.70 & 2.70 & 0.019 & 2.20 \\
\hline Within Groups & 527.6 & 36 & 14.65556 & & & \\
\hline Total & 845.2444 & 44 & & & & \\
\hline
\end{tabular}

The ANOVA test (table 4) yielded an F value of 2.7. Since the calculated F-value of 2.7 is greater than the critical F value 
of 2.20 ie $(2.7<2.20)$, we rejected our hypothesis. Thus there is some significant difference among households in terms of their coping strategies to flood.

To determine the factors influencing the coping strategies practiced by the households, a Principle Component Analysis (PCA) was performed. The PCA collapsed the10 variables into four major components. The variables, their component loadings, Eigen values, variance percentage and cumulative percentage of total variance explained by each component are presented as table 5

Table 5: Rotated Component factor influencing coping strategies in the study area.

\begin{tabular}{|c|l|c|c|c|}
\hline & & \multicolumn{3}{|c|}{ Components } \\
\hline Variables & Variable name & 1 & 2 & 3 \\
\hline Var I & lack of alternative livelihood & .363 & .058 & $(.748)$ \\
\hline Var II & lack of personal funds & $(0.670)$ & -.377 & .134 \\
\hline Var III & religious altitude & .063 & .125 & -.938 \\
\hline Var IV & Level of literacy & $(.841)$ & -.333 & .318 \\
\hline Var V & vulnerability of property/farmland & -.635 & $(.638)$ & -.314 \\
\hline Var VI & Help from extended family relations & -.339 & -.715 & .028 \\
\hline Var VII & Reliance on govt/community interventions & .003 & $. .742)$ & .266 \\
\hline Var VIII & lack of credit facility & $(.825)$ & -.076 & -.323 \\
\hline Var IX & personal choice & -.178 & $(.768)$ & -.196 \\
\hline Var X & nature of occupation/farm size & $(.800)$ & .211 & .420 \\
\hline & Eigen & 3.161 & 2.380 & 2.050 \\
\cline { 2 - 5 } & Variance \% & 31.610 & 23.802 & 20.504 \\
\cline { 2 - 5 } & Cumulative \% & 31.610 & 55.412 & 75.916 \\
\hline
\end{tabular}

Table 5 shows that component I explaining $31.6 \%$ of the total variance is the most important. High loadings on this component were recorded for lack of personal funds (II), lack of credit facility (Var.VIII) and nature of occupation/farm size (Var.X). This component suggests poverty level. Component II explaining $23.8 \%$ of the total variance has high loadings on vulnerability of property/farm land to flood impact (Var.V), reliance on government/community intervention (Var. VII) and personal choice (Var. IX). This component is thus an index of vulnerability of farm lands/properties to flood disaster. Component III explains $20.5 \%$ of the total variance and has high loadings only on lack of alternative livelihood (Var. 1). Together the three components explain $75.9 \%$ of variation in the factors influencing flood coping strategies, leaving 24.1\% unexplained. Thus the influencing factors in terms of the female headed households flood coping strategies depends on their poverty level, vulnerability of their farm lands/properties to flooding and having lack of alternative.

\section{Conclusion and Recommendations}

The study revealed that various categories of female headed households exist in the community and their sources of livelihood are mainly were affected during the 2012 floods. The staple crops were destroyed and this affected household food security. The flood coping strategies adopted by the households range from forced temporary migration from the flood plains to changing means of livelihood to another. The most popular strategy being forced temporary migration especially as most of them are not indigenes of the community. The analysis of variance indicated that there is significant difference among households in terms of their coping strategies to flood. A principal component analysis identified three major factors that influence flood coping strategies as poverty level, vulnerability of farm lands/properties to flood disaster and lack of alternative livelihood.

It is noteworthy that although there are some current flood coping strategies being practiced by female headed households in the community, there are not very effective. Discussion with them established the fact that the coping strategies were not sustainable especially forced temporary migration and borrowing of funds. The local community's coping strategies/capacities should not be under estimated but rather built upon. The major focus must be on improving the livelihood condition of female headed households especially during and after the floods. The study recommends as follows

- awareness should be created as regards the need not to build houses/farm around the flood plain areas.

- there is need to review the land ownership to empower those in flood plains of the river Niger to relocate to the upper lands in the community. 
- Assistance to flood victims should be extended beyond just the period of flood. Programmes to assist their rehabilitation/recovery long after the flood is to be established both at the level of the government, community and kindred.

- Community based flood warning systems that will aid livelihood sustenance should be developed.

\section{References}

Amin, Sajeda,( 1996): Family Structure and Change In Rural Bangladesh, Working Paper, The Population Council, No. 87.a

Abayomi Samuel Oyekale, J (2013): Impact of Flooding on the Health of Coastal Fishing Folks in Epe Division of Lagos State, Nigeria Ecology, 44(2): 183-188

Ariyanbandu, M.M. and Wackramasinghe, W.M. (2005.) Gender Dimension in Disaster Management: A guide for South Asia: Sri Lanka.

Blaikie, P., T. Cannon, I. Davis, and B. Wisner (1994): At risk: natural hazards, people's Vulnerability, and Disasters. Routledge, London UK..

Borrows, P. and De Bruin, D (2006): "The Management of Riverine Flood Risk". Irrigation and Drainage 55 (1), 51-5157.

Buvinic, M., and G. R. Gupta (1997): "Female-Headed Households and Female-Maintained Families: Are They Worth Targeting to Reduce Poverty in Developing Countries?" Economic Development and Cultural Change 45(2): 259-280

Cain, M. T., Khanam S. R., and Nahar. S. (1979): "Class, patriarchy, and women's work in Bangladesh, Population and Development Review". 5(3):405-438.

Caldwell, J, P.H. Reddy, P.H. and Caldwell, P: (1984) Investigating the nature of population change in South India. Paper presented at IUSSP Seminar on Micro-Approaches to Demographic Research, Australian National University, Canberra.

Caldwell, John C., G. Immerwahr, and L. T. Ruzicka, (1985): "The nuclearization of the joint family households in a rural area of Bangladesh", Journal of Comparative Family Studies, 16(3).

Dercon, S. (2001): Assessing Vulnerability to Poverty, Center for the Study of African Economies, Department of Economies, Oxford University.

Dixit, A. (2003): "Floods and Vulnerability: Need to Rethink Flood Management". Natural Disaster ,28:155-179.

Enarson, Elaine (1998a): "Through Women's Eyes: A gendered Research agenda for social science”, Journal of Disaster Studies, Policy and Management 22:2. International flood Initiative (2003)

Islam, Mahmuda, 1993, "Female-Headed Households in Rural Bangladesh: A Survey", In: Where Did All the Men Go? edited by Joan P. Mencher and Anne Okongwu, Westview Press, pp. 233-242

Hunter, L. (2005): "Migration and environmental hazards". Population and Environment, 26(4): 273-302

Handa, S., (1994): "Gender, Headship and Intra-household Resource Allocation", World Development, 22(10):1535-1547.

Kolawole O.M, Olayemi A.B, Ajayi K.T (2011): "Managing flood in Nigerian cities: Risk analysis and adaptation options - Ilorin city as a case study". Archives of Applied Science Research, 3 (1): 17-24

Mnirul, M, Mirza, Q, Dixit, A. and Nishat, A. (2003.): Speacial Issue on flood Problems and Management in South Asia Preface. Natural Hazards. vol 28, issue 1, pp vii-ix.fo

Mbugua, W (1997) "The African Family and the Status of Women's Health", in: Aderanti Adepoju (ed) Family, Population and Development in Africa, London, ZedBooks Ltd: 139-157.r

Parker, J.D. ( 2000) Floods. Tangler and Francis, National Academy Press, Asian Disaster Preparedness Centre, Thailand.

Odufuwa BO, Adedeji OH, Oladesu JO, Bongwa A (2012). "Floods of Fury in Nigerian Cities", Journal of Sustainable Development. 5(7)

Oppong, C (1997) "The African Family and the Status of Women's Health", in: Aderanti Adepoju (ed.) Family, Population and Development in Africa, London, ZedBooks Ltd: 158-182.

Rahman, Omar . M( 1998):"Family Matters: The Impact of Kin on Elderly Mortality in Rural Bangladesh", Population Studies, vol 52 (2), 227-235.

Sen, A.K (1987) : The Standard of Living, Cambridge: Cambridge University Press.

Quisumbing, A. R., L. Haddad, and C. Pena, 2001, "Are Women Overrepresented Among the Poor? An Analysis of Poverty in Ten Developing Countries." Journal of Development Economics 66(1): 225-269.

Rashid, F.S.( 2000.) : "The Urban Poor in Dhaka City: Their Struggles and coping strategies during the floods of 1998". Disasters, 20(3), 240-253.

Smith, K .and Ward, R. (1998): Floods: Physical processes and Human Impacts. John Wiley and son. England.

Uddin, K; Gururg, D; Girira, A and Shretha, B(2013): "Application of Remote Sensing and GIS for Flood Hazard Management: A case study from Sindh Province Pakistan". American Journal of Geographic Information System 2(1), 1-5.

UNEP (2006): Gathering Storm: The Humanitarian Impact of Climate Change.

UN ISDR (2009) Making Disaster Risk Reduction Gender Sensitive Policy and Practical Guidelines. http://www.unisdr.org/europe/ publications/ v.php?id=9922

United Nations (2009): 2009 Global Assessment Report on Disaster Risk Reduction: Risk and Poverty in a Changing Climate, UNISDR, Geneva, 207pp. Available at http://www.preventionweb.net/english/hyogo/gar/?pid:3\&pil:1 (Accessed 11 August 2011).

UN ISDR (2009) Global Assessment Report on Disaster Risk Reduction: Risk and Poverty in a changing Climate. Invest today for a safer tomorrow. www.preventionweb.net/files/9414-GARsummary.pdf.

World Bank (1991): Gender and Poverty in India. Report 807:2-IN. Washington, D.C. 
